J. Clin. Chem. Clin. Biochem.

Vol. 24, 1986, pp. $465-470$

(C) 1986 Walter de Gruyter \& Co.

Berlin - New York

\title{
Urinary Excretion of 3-Methylhistidine and Creatinine by Healthy Dutch Children During Day and Night. The Influence of Age and Sex
}

\author{
By A.J. Speek
}

TNO-CIVO Toxicology and Nutrition Institute, Department of Clinical Biochemistry, Zeist, The Netherlands

\section{J.T. N. M. Thissen}

Institute for Mathematics, Information Processing and Statistics TNO, Wageningen, The Netherlands and

\section{J. Schrijver}

TNO-CIVO Toxicology and Nutrition Institute, Department of Clinical Biochemistry, Zeist, The Netherlands

(Received June 14/October 25, 1985/February 7, 1986)

Summary: The urinary excretion of 3-methylhistidine and creatinine and the urinary 3-methylhistidine to creatinine excretion ratio during day and night were investigated in a group of 103 healthy, normally fed Dutch children ( 52 boys and 51 girls) aged $2-17$ years.

The 3-methylhistidine to creatinine ratio of the night urine appeared to be significantly higher than that of the urine produced during the day, irrespective of sex and age. This difference was about $30 \%$. For both sexes it was found that the 3-methylhistidine and creatinine excretion increased and that the 3-methylhistidine to creatinine ratio decreased with age. Although the creatinine excretion by boys was significantly higher than that by girls of the same age, no differences were seen between the sexes with respect to the 3methylhistidine excretion or the 3-methylhistidine to creatinine ratio. A clear linear relation was found between the day or night urine and the $24 \mathrm{~h}$ urine with respect to the 3-methylhistidine to creatinine ratio. However, no such relation was observed between the day and the night urine.

These results are discussed in relation to the use of smaller urine samples instead of 24 hour urine in the study of 3-methylhistidine excretion.

Ausscheidung von 3-Methylhistidin und Kreatinin im Harn bei gesunden niederländischen Kindern während Tag und Nacht

Der Einfluß von Alter und Geschlecht

Züsammenfassung: Die Ausscheidung von 3-Methylhistidin und Kreatinin im Harn und der Quotient der Ausscheidung von 3-Methylhistidin zu Kreatinin bei Tag und Nacht wurden bei einer Gruppe von 103 gesunden, normal ernährten niederländischen Kindern (52 Jungen, 51 Mädchen im Alter von 2 bis 17 Jahren) untersucht.

Der Quotient von 3-Methylhistidin und Kreatinin im Nachtharn schien signifikant höher als der im Tagesharn und war unabhängig von Geschlecht und Alter. Diese Differenz betrug etwa 30\%. Für beide Geschlechter wurde festgestellt, daß die 3-Methylhistidin- und Kreatinin-Ausscheidung mit dem Alter anstieg und der Quotient von 3-Methylhistidin und Kreatinin mit dem Alter abnahm. Obwohl die Kreatininausscheidung im 
Harn der Jungen signifikant höher war als bei den Mädchen gleichen Alters, wurden zwischen beiden Geschlechtern keine Unterschiede hinsichtlich der 3-Methylhistidin-Ausscheidung oder des Quotienten von 3-Methylhistidin und Kreatinin beobachtet. Eine deutliche lineare Beziehung wurde zwischen dem Tag- oder Nacht-Harn und dem 24 Stunden-Harn hinsichtlich des Quotienten von 3-Methylhistidin und Kreatinin gefunden. Eine solche Beziehung wurde jedoch zwischen dem Tag- und Nachtharn nicht beobachtet. Diese Ergebnisse werden unter dem Aspekt diskutiert, geringere Harnproben anstelle des 24 Stunden-Harns für die Untersuchung der 3-Methylhistidinausscheidung einzusetzen.

\section{Introduction}

Evidence has been reported that the urinary excretion of 3-methylhistidine may be used as an index of skeletal muscle protein breakdown in human subjects (1). Furthermore, since the total body pool of skeletal muscle can be estimated from the excretion rate of creatinine (2), the excretion ratio of 3-methylhistidine to creatinine reflects the fractional turnover of muscle protein.

However, 3-methylhistidine present in dietary meat may contribute to a considerable extent to the total urinary excretion of this histidine derivative. Therefore, a three day meat-free diet before the collection of 24 hour urine is needed. Both conditions (meat-free period and 24 hour collection period) are generally recognized as limitations in the use of the 3-methylhistidine to creatinine excretion ratio (3). In practice, especially with non-hospitalized infants and children, it is generally not possible to introduce a period of three days on a meat free diet, while collection of 24 hour urine can hardly be achieved.

Nutritional deprivation during early life will result in less striated muscle mass and thereby in a lower urinary excretion of creatinine (4). Furthermore, a lower creatinine excretion may also partly be explained by a lower consumption of meat. Similar relationships are to be expected for 3-methylhistidine.

We wish to investigate the use of the urinary 3methylhistidine and creatinine excretion in surveys of well- and malnourished children (developing $v s$ developed countries) in relation to meat consumption and muscle mass. It was therefore of interest to consider the potential informative value of an untimed urine portion, especially since standardized conditions in such surveys can hardly be achieved. The urinary excretion of 3-methylhistidine has so far been reported only for small groups of infants and children $(5,6)$.

Therefore, we initiated investigations on the nighttime and day-time urinary excretion of 3-methylhistidine and creatinine by healthy, normally fed Dutch children.

\section{Materials and Methods}

\section{Subjects and urine samples}

In total 103 healthy Dutch children ( 52 boys and 51 girls) ranging in age from 2 to 17 years (mean \pm standard error $=$ $9.9 \pm 3.5$ ) volunteered in our study. In all children no signs of clinical disorders were present. Their food pattern was normal, i. e. practically every day three meals were taken (breakfast, lunch and hot meal) and no instructions were given with respect to their diet. Most of the meat consumed was taken during dinner. None of these children was on a diet. No vegan or vegetarian children took part in our study. In our group of children about $20 \%$ of the total amount of protein consumed during the day originated from meat products. The average daily intake of meat protein for the respective groups of children was $11 \mathrm{~g}$ ( $2-5$ years), $16 \mathrm{~g}$ (6-9 years), $15 \mathrm{~g}$ (10-13 years) and $24 \mathrm{~g}$ (14-17 years). The inter-person variation of the meat protein intake was about $30 \%$. In general, the ratio of the amounts of meat protein consumed during dinner and lunch was approximately $3: 2$.

Some characteristics of both groups of children investigated are given in table 1 . In the same age range no significant differences were observed with respect to age, body length (upright position) and body weight (as dressed). The actual figures obtained do not deviate from those which are normally found in Dutch children $(7,8)$.

During a period of 24 hours urine was collected as separate day and night urine. Night urine was defined as the amount excreted during the sleeping period and immediately after awakening in the morning. The urine excreted during the remainder of the 24 hour period was considered as day urine. Urine was collected directly into polyethylene vessels. After collection, urine samples were acidified by the addition of $10 \mathrm{ml} 5 \mathrm{~mol} / \mathrm{l}$ $\mathrm{HCl}$ per liter urine and stored at $-20^{\circ} \mathrm{C}$.

\section{Methods of analysis}

Aliquots of $0.2 \mathrm{ml}$ urine were diluted with $2 \mathrm{ml} 6 \mathrm{~mol} / \mathrm{l} \mathrm{HCl}$. Thereafter, the concentration of 3-methylhistidine was determined after pre-column derivatization by high performance liquid chromatography with fluorometric detection according to the method described by $D e$ Jong et al. (9) for meat hydrolysates.

In this method $0.2 \mathrm{ml}$ of the acidified urine sample was mixed with $2.2 \mathrm{ml}$ of a solution containing $0.17 \mathrm{~mol} / 1$ sodium tetraborate and $0.55 \mathrm{~mol} / 1 \mathrm{NaOH}$, followed by $2.5 \mathrm{ml}$ of a freshly prepared solution of fluorescamine in acetonitrile $(2.5 \mathrm{~g} / \mathrm{l})$. Thereafter, $2.5 \mathrm{ml} 2 \mathrm{~mol} / 1 \mathrm{HCl}$ was added and the final solution was heated for $60 \mathrm{~min}$ at $80^{\circ} \mathrm{C}$ on a water bath. After cooling to $+4{ }^{\circ} \mathrm{C}$, the solution was centrifuged for $5 \mathrm{~min}$ at $+4^{\circ} \mathrm{C}$ and $5000 \mathrm{~g}$. The supernatant was used for the chromatographic analysis of 3-methylhistidine. An amount of $30 \mu \mathrm{l}$ was injected onto a Hyperchrome column (100 $\times 3.3 \mathrm{~mm}$ intêrnal diameter $)$ filled with Hypersil-ODS (Shandon, 'Zeist, The Netherlands). 
Tab. 1. Some characteristics of the boys and girls investigated.

\begin{tabular}{|c|c|c|c|c|c|c|c|}
\hline \multicolumn{2}{|c|}{$\begin{array}{l}\text { Number of } \\
\text { children }\end{array}$} & \multicolumn{2}{|l|}{$\begin{array}{l}\text { Age } \\
\text { (years) }\end{array}$} & \multicolumn{2}{|l|}{$\begin{array}{l}\text { Body length } \\
\text { (cm) }\end{array}$} & \multicolumn{2}{|l|}{$\begin{array}{l}\text { Body weight } \\
(\mathrm{kg})\end{array}$} \\
\hline Boys & Girls & Boys & Girls & Boys & Girls & Boys & Girls \\
\hline 8 & 12 & $\begin{array}{l}4.8 \pm 1.2 \\
2.4-5.9\end{array}$ & $\begin{array}{l}4.5 \pm 0.8 \\
3.3-5.9\end{array}$ & $\begin{array}{r}112 \pm 16 \\
82-128\end{array}$ & $\begin{array}{l}110 \pm 7 \\
103-127\end{array}$ & $\begin{array}{l}19.6 \pm 3.9 \\
13=27\end{array}$ & $\begin{array}{l}18.8 \pm 3.2 \\
15=24\end{array}$ \\
\hline 19 & 20 & $\begin{array}{l}8.2 \pm 1.1 \\
6.2=9.7\end{array}$ & $\begin{array}{l}8.1 \pm 1.1 \\
6.2=9.7\end{array}$ & $\begin{array}{l}131 \pm 11 \\
116-156\end{array}$ & $\begin{array}{l}134 \pm 11 \\
120-156\end{array}$ & $\begin{array}{l}25.8 \pm 4.8 \\
18=37\end{array}$ & $\begin{array}{l}28.3 \pm 6.0 \\
20=44\end{array}$ \\
\hline 20 & 10 & $\begin{array}{l}12.1 \pm 1.1 \\
10.0 \pm 13.9\end{array}$ & $\begin{array}{l}11.4 \pm 1.2 \\
10.0-13.9\end{array}$ & $\begin{array}{l}153 \pm 8 \\
141-171\end{array}$ & $\begin{array}{l}149 \pm 8 \\
135-163\end{array}$ & $\begin{array}{l}36.8 \pm 5.9 \\
28-51\end{array}$ & $\begin{array}{l}37.4 \pm 10.4 \\
28-63\end{array}$ \\
\hline 5 & 9. & $\begin{array}{l}15.9 \pm 1.1 \\
14.7\end{array}$ & $\begin{array}{l}15.1 \pm 0.6 \\
14.1-16.0\end{array}$ & $\begin{array}{l}171 \pm 7 \\
165-180\end{array}$ & $\begin{array}{l}168 \pm 5 \\
156-173\end{array}$ & $\begin{array}{l}54.8 \pm 9.4 \\
45-68\end{array}$ & $\begin{array}{l}53.5 \pm 7.5 \\
36-61\end{array}$ \\
\hline
\end{tabular}

Values are given as mean \pm standard error and as $95 \%$ ranges ( $2.5-\mathrm{p} 97.5)$.

A $2 \mathrm{~cm} \mathrm{RP-18} \mathrm{cartridge} \mathrm{was} \mathrm{used} \mathrm{as} \mathrm{a} \mathrm{pre-column.} \mathrm{The} \mathrm{column}$ was eluted with a mobile phase containing $3 \mathrm{mmol} / 1 \mathrm{~K}_{2} \mathrm{HPO}_{4}$, $3 \mathrm{mmol} / 1 \mathrm{NaH}_{2} \mathrm{PO}_{4}, 0.6 \mathrm{~g} / \mathrm{l}$ valeric acid and methanol (volume fraction 0.42 ) adjusted to $\mathrm{pH} 7.9$ with $\mathrm{NaOH}$.

The flow rate of the mobile phase was $1.3 \mathrm{ml} / \mathrm{min}$ and the effluent of the column was monitored by fluorescence detection using a Shimadzu fluorescence detector type RF 530 set at the wavelength couple $360 / 455 \mathrm{~nm}$. Recordings were done at $10 \mathrm{mV}$ full scale and a chart speed of $2 \mathrm{~mm} / \mathrm{min}$.

Urinary creatinine was determined using the Boehringer kit No. 124192 (Boehringer Mannheim GmbH, Federal Republic of Germany) based on colorimetric measurement of the reaction product of creatinine and picric acid.

Analytical results were evaluated statistically by regression analysis and analysis of variance (split-plot) using the Genstat $\mathrm{V}$ statistical programme (10) run on a VAX $11 / 750$ computer (Digital Equipment Corporation).

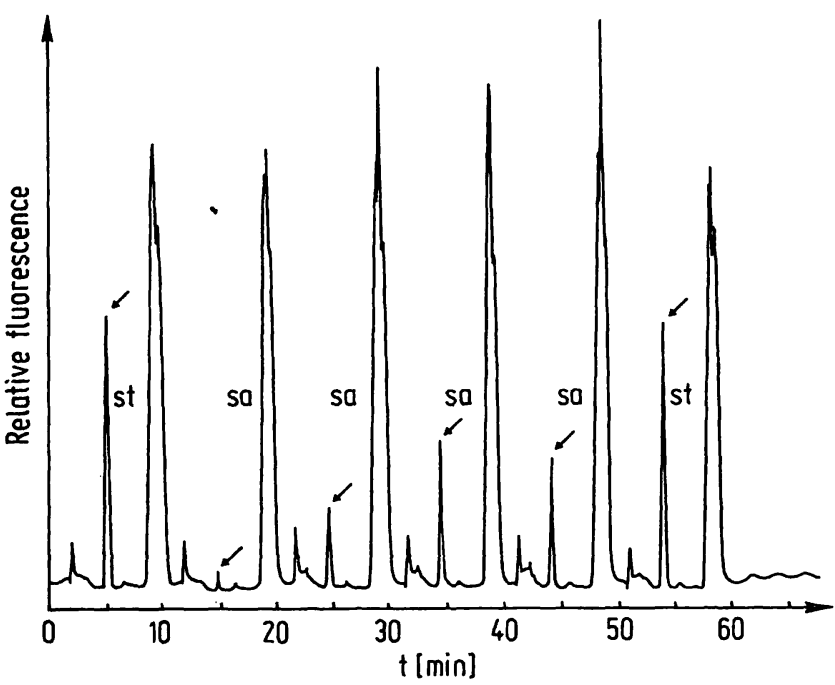

Fig. 1. Typical high performance liquid chromatographic elution profiles of a working standard solution (st) and of urine samples (sa). The arrow indicates the fluorescamine derivative of 3-methylhistidine.

\section{Results}

Characteristics of the high performance liquid chromatographic analysis of 3-methylhistidine

Typical elution profiles of derivatized urine samples and standard solution are shown in figure 1. The chromatographic procedure afforded an excellent separation of the 3-methylhistidine derivative from other urine components. If the lowest acceptable signal to noise ratio is three, then the detection limit for the analysis of 3-methylhistidine is as low as $3 \mu \mathrm{mol} / 1$ urine. The between assay coefficient of variation was $6.2 \%$ for ten series using a urine sample with a 3methylhistidine concentration of $320 \mu \mathrm{mol} / 1$. In routine analysis, a concentration as low as $5 \mu \mathrm{mol} 3-$ methylhistidine per litre urine could easily be detected.
3-Methylhistidine and creatinine excretion in relation to age and sex

The observed urinary (night, day and 24 hour) 3methylhistidine to creatinine excretion ratios and the separate urinary excretion of 3-methylhistidine and of creatinine are given in tables 2 to 4 .

Analysis of variance showed that, irrespective of age and sex, the 3-methylhistidine to creatinine ratio of the night urine was significantly $(p<0.001)$ higher than that of the day urine. The average difference was about $25 \%$ (tab. 2).

The influence of age and sex on the excretion levels was investigated using regression analysis. It was found that for both sexes the excretion of 3-methylhistidine and of creatinine significantly $(p<0.01)$ 
increased with age (tab. 3 and 4). However, the 3methylhistidine to creatinine ratio decreased with age, indicating a stronger increase of creatinine excretion with age as compared with 3-methylhistidine (tab. 2). In the age range investigated $(2-17$ years) the 3methylhistidine to creatinine ratio decreased by about $10 \mathrm{mmol} / \mathrm{mol}$ per 10 years.
The effect of sex adjusted for age was only significant $(p<0.025)$ in the case of the urinary excretion of creatinine (tab. 3), although for boys at all ages the urinary excretion of 3-methylhistidine tended to be higher than that of girls $(0.05<\mathrm{p}<0.1)$.

Tab. 2. The 3-methylhistidine to creatinine excretion ratio in urine of boys and girls.

\begin{tabular}{|c|c|c|c|c|c|c|c|}
\hline \multirow{3}{*}{$\begin{array}{l}\text { Age } \\
\text { (years) } \\
\text { Range }\end{array}$} & \multicolumn{7}{|c|}{ 3-Methylhistidine/creatinine } \\
\hline & \multicolumn{3}{|l|}{ Boys } & & \multicolumn{3}{|l|}{ Girls } \\
\hline & Night & Day & 24 hours & & Night & Day & 24 hours \\
\hline $2-5$ & $\begin{array}{l}46.5 \pm 9.7 \\
37.6-66.3\end{array}$ & $\begin{array}{l}31.7 \pm 11.2 \\
11.1=47.9\end{array}$ & $\begin{array}{l}36.9 \pm 9.4 \\
22.4-50.8\end{array}$ & $\begin{array}{l}(\mathrm{mmol} / \mathrm{mol}) \\
(\mathrm{mmol} / \mathrm{mol})\end{array}$ & $\begin{array}{l}42.0 \pm 14.7 \\
24.1=68.3\end{array}$ & $\begin{array}{l}35.5 \pm 13.4 \\
21.2 \pm 71.5\end{array}$ & $\begin{array}{l}36.9 \pm 9.6 \\
24.6 \div 52.9\end{array}$ \\
\hline $6-9$ & $\begin{array}{l}40.5 \pm 14.6 \\
25.4-85.8\end{array}$ & $\begin{array}{l}33.4 \pm 10.7 \\
17.8-64.1\end{array}$ & $\begin{array}{l}37.6 \pm 9.8 \\
25.0-59.9\end{array}$ & $\begin{array}{l}(\mathrm{mmol} / \mathrm{mol}) \\
(\mathrm{mmol} / \mathrm{mol})\end{array}$ & $\begin{array}{l}39.4 \pm 12.5 \\
20.5-61.9\end{array}$ & $\begin{array}{l}33.3 \pm 11.7 \\
22.7 \pm 65.0\end{array}$ & $\begin{array}{l}36.3 \pm 9.8 \\
23.0=60.2\end{array}$ \\
\hline $10-13$ & $\begin{array}{l}42.0 \pm 19.9 \\
17.4-85.7\end{array}$ & $\begin{array}{l}27.7 \pm 7.4 \\
12.8-42.1\end{array}$ & $\begin{array}{l}33.0 \pm 9.2 \\
18.0=48.5\end{array}$ & $\begin{array}{l}(\mathrm{mmol} / \mathrm{mol}) \\
(\mathrm{mmol} / \mathrm{mol})\end{array}$ & $\begin{array}{l}34.0 \pm 14.7 \\
15.0 \pm 59.9\end{array}$ & $\begin{array}{r}30.1 \pm 12.3 \\
6.9-56.6\end{array}$ & $\begin{array}{l}32.2 \pm 11.1 \\
11.2-48.2\end{array}$ \\
\hline $14-17$ & $\begin{array}{l}28.8 \pm 10.7 \\
15.3-46.2\end{array}$ & $\begin{array}{l}23.4 \pm 7.0 \\
15.9-36.2\end{array}$ & $\begin{array}{l}25.6 \pm 7.2 \\
18.2-35.0\end{array}$ & $\begin{array}{l}(\mathrm{mmol} / \mathrm{mol}) \\
(\mathrm{mmol} / \mathrm{mol})\end{array}$ & $\begin{array}{l}27.8 \pm 4.1 \\
22.7 \pm 35.6\end{array}$ & $\begin{array}{l}27.3 \pm 11.6 \\
18.6-53.6\end{array}$ & $\begin{array}{r}25.7 \pm 5.8 \\
21.9-39.9\end{array}$ \\
\hline
\end{tabular}

Values are given as mean \pm standard error and as $95 \%$ ranges (p2.5-p97.5).

Tab. 3. The 24 hour urinary excretion of 3-methylhistidine and creatinine by boys and girls.

\begin{tabular}{llllll}
\hline $\begin{array}{l}\text { Age } \\
\text { (years) }\end{array}$ & \multicolumn{2}{l}{$\begin{array}{l}\text { 3-Methylhistidine } \\
(\mu \mathrm{mol})\end{array}$} & \multicolumn{1}{l}{$\begin{array}{l}\text { Creatinine } \\
\text { (mmol) }\end{array}$} \\
\cline { 2 - 5 } & Boys & Girls & Boys & Girls \\
\hline $2-5$ & $105.3 \pm 31.5$ & $79.5 \pm 22.3$ & $3.03 \pm 1.12$ & $2.23 \pm 0.62$ \\
& $65.7-153.0$ & $31.3-111.1$ & $1.30 \pm 4.70$ & $0.80-3.13$ \\
$6-9$ & $159.7 \pm 53.4$ & $155.4 \pm 50.0$ & $4.33 \pm 1.36$ & $4.11 \pm 0.89$ \\
& $95.8-272.7$ & $104.0-266.4$ & $2.56 \pm 8.57$ & $2.47-5.69$ \\
$10-13$ & $224.4 \pm 59.8$ & $212.3 \pm 57.3$ & $7.13 \pm 1.57$ & $6.19 \pm 1.57$ \\
& $124.0-330.2$ & $102.8-270.8$ & $4.31-10.72$ & $3.73-9.01$ \\
$14-17$ & $287.1 \pm 115.2$ & $216.8 \pm 57.1$ & $11.64 \pm 4.20$ & $8.04 \pm 2.03$ \\
& $175.4-454.2$ & $160.5-347.8$ & $5.02-14.99$ & $4.08-11.76$ \\
\hline
\end{tabular}

Values are given as mean \pm standard error and as $95 \%$ ranges $(\mathrm{p} 2.5-\mathrm{p} 97.5)$.

Tab. 4. The urinary excretion of 3-methylhistidine and creatinine by boys and girls during day and night.

\begin{tabular}{|c|c|c|c|c|c|c|c|c|}
\hline \multirow{3}{*}{$\begin{array}{l}\text { Age } \\
\text { (years) } \\
\text { Range }\end{array}$} & \multicolumn{4}{|c|}{$\begin{array}{l}\text { 3-Methylhistidine } \\
\text { ( } \mu \mathrm{mol})\end{array}$} & \multicolumn{4}{|l|}{$\begin{array}{l}\text { Creatinine } \\
\text { (mmol) }\end{array}$} \\
\hline & \multicolumn{2}{|l|}{ Boys } & \multicolumn{2}{|l|}{ Girls } & \multicolumn{2}{|l|}{ Boys } & \multicolumn{2}{|l|}{ Girls } \\
\hline & Night & Day & Night & Day & Night & Day & Night, & Day \\
\hline $\begin{array}{r}2-5 \\
6-9 \\
10-13 \\
14-17\end{array}$ & $\begin{array}{l}26.3-80.9 \\
23.2-142.8 \\
41.7-178.0 \\
58.4-217.7\end{array}$ & $\begin{array}{l}28.9-90.5 \\
40.7-131.6 \\
43.4-223.0 \\
98.5-236.5\end{array}$ & $\begin{array}{r}4.9-73.0 \\
14.0-137.4 \\
38.1-142.4 \\
61.4-130.2\end{array}$ & $\begin{array}{l}21.1-77.9 \\
20.3-249.4 \\
56.0-216.0 \\
74.2-217.6\end{array}$ & $\begin{array}{l}0.45-2.05 \\
0.65-4.25 \\
0.94-6.21 \\
1.81-8.87\end{array}$ & $\begin{array}{l}0.84-2.94 \\
1.14-4.32 \\
1.83-7.43 \\
3.21-10.56\end{array}$ & $\begin{array}{l}0.12-1.73 \\
0.92-3.47 \\
1.45-4.53 \\
2.23-4.49\end{array}$ & $\begin{array}{l}0.51-2.49 \\
0.76-4.30 \\
2.03-4.84 \\
1.85-8.01\end{array}$ \\
\hline
\end{tabular}


The 3-methylhistidine to creatinine ratio in relation to the type of urine

The relation between the 3-methylhistidine to creatinine ratio of the 24 hour urine and these ratios of the corresponding night and day urines was investigated by regression analysis.

Regarding the 3-methylhistidine to creatinine ratio, not taking into account the influence of age and sex, a linear relation could be established between the day as well as the night urine and the 24 hour urine. The regression coefficients clearly differed from zero. However, no such significant linear relation was found between these ratios for day and night urine. Figure 2 shows the plot of the individual data of the 24 hour and the night urines, together with the calculated regression line.

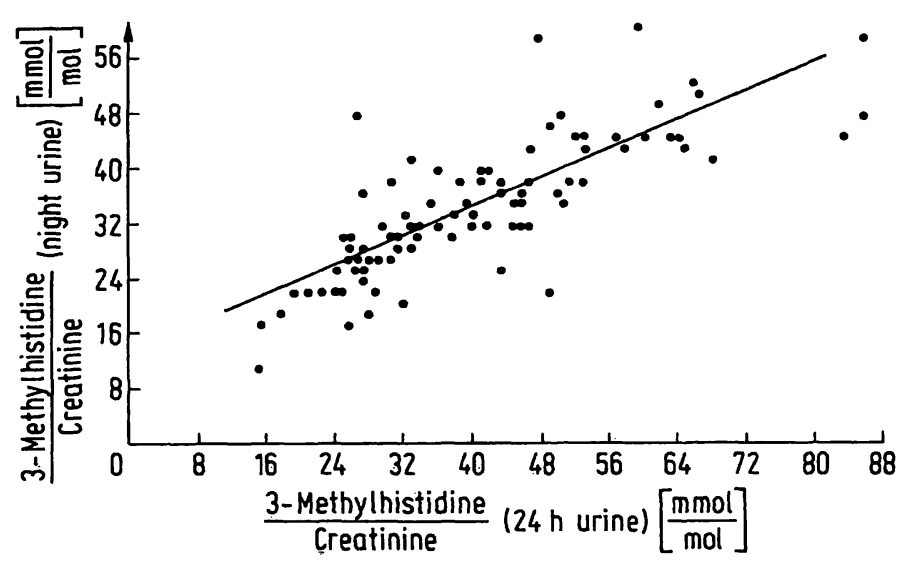

Fig. 2. Plot of the individual data of the 3-methylhistidine to creatinine ratios (mmol/mol) of the 24 hour and night urines together with the calculated regression line. For further details see the text.

Adding the factor sex to the regression model did not improve the fits. Howëver, when the factor age was added, significantly $(p<0.01)$ better fits were obtained.

The calculated regression equation for the night urine was in that case:

$[\mathrm{y}]=\mathrm{c}_{1}[\mathrm{x}]+\mathrm{c}_{2}[\mathrm{z}]+\mathrm{c}_{3}$,

in which [y] and [x] are the ratios in the 24 hour and night urine respectively, $[\mathrm{z}]$ is the age in years, and the coefficients:

$c_{1}=0.49 \pm 0.04, c_{2}=0.46 \pm 0.17$ and $c_{3}=19.6$ \pm 2.6. The standard deviation of residuals was 5.95 . All values are given as mmol 3-methylhistidine per mol creatinine.

\section{Discussion}

The creatinine and 3-methylhistidine excretion

The creatinine excretion and its age and sex dependencies as observed in our study are in good agreement with the results of the investigations of Applegarth \& Ross (11) carried out with children of up to 10 years and with those obtained and elaborately described by Clark et al. (12). Rao \& Nagabushan (5) reported an investigation on 3-methylhistidine excretion by infected children. The values obtained from 4 normal, healthy children, their control group, are considerably lower (mean: $36 \mu$ mol 3-methylhistidine per 24 hour) than our results (mean: $173 \mu \mathrm{mol} /$ $24 \mathrm{~h}$ ). Most probably, different dietary habits and muscle mass will chiefly account for this difference.

The 3-methylhistidine to creatinine excretion ratio.

Considering the results obtained for the night and day urine, it is notable that the variation of the 3methylhistidine to creatinine ratio is higher than that of the 24 hour urine (see the standard errors given in tab. 2). This is most probably due to differences between the children with respect to the time of the day for meat consumption and duration of the sleeping period. The higher excretion of 3-methylhistidine with the night urine is most probably the result of the time of meat consumption, which regularly takes place in the afternoon.

According to Calles-Escadon (13), differences in physical activity do not influence the 3-methylhistidine to creatinine excretion ratio in adults. Maybe this also applies to children. In spite of these relatively large variations, clear linear relations were found between the 3-methylhistidine to creatinine ratio of the 24 hour urine and that of each of the other types of urine (day and night), as theoretically expected.

\section{Conclusion}

For surveys with children aged $2-17$ years, the following conclusion can be drawn.

Provided sufficiently large groups of children are investigated, an untimed urine specimen (i. c. night urine) can be used instead of the 24 hour urine to study differences between groups of children (in the age range of $2-17$ years) with respect to the excretion of 3-methylhistidine. This excretion should be examined in relation to that of creatinine. 


\section{Acknowledgement}

Grateful acknowledgement is made to Prof. Dr. F. P. Schelp from the Faculty of Tropical Medicine of the Mahidol Univer-

\section{References}

1. Ballard, F. J. \& Tomas, F. M. (1983) Clin. Sci. 65, 209-215.

2. Heymsfield, S. B., Arteaga, C., McManus, C., Smith, J. \& Moffit, S. (1983) Am. J. Clin. Nutr. 37, 478-494.

3. Tomas, F. M., Ballard, F. J. \& Pope, L. M. (1979) Clin. Sci. $56,341-346$.

4. Satyanarayana, K., Naidu, A. N. \& Rao, B. S. N. (1981) Am. J. Clin. Nutr. 34, 161-165.

5. Rao, B. S. N. \& Nagabhushan, V. S. (1973) Life Sci. 12, 205-210.

6. Pencharz, P. B., Masson, M., Desgranges, F. \& Papageorgiou, A. (1984) Nutr. Res. 4, 9-19.

7. Egger, R. J., Hulshof, K. F. A. M., Nefkens, V. J. M., Meihuizen, I. K. \& van Rossen, D. S. (1982) Netherl. J. Nutr. $43,362-373$. sity, Bangkok, and Institut für Soziale Medizin, Freie Universität Berlin, for his suggestions during the preparation of the manuscript.

8. Luyken, R., Luyken-Koning, F. W. M., Thissèn, J. T. N. M. \& de Wijn, J. F. (1985) Netherl. J. Nutr. 47, 24-32.

9. de Jong, A. W. J., de Bie, A. T. H. J., Hensen, R. \& van Biert, M. (1985) J. Chromatogr., submitted.

10. Nelder, J. A. and members of the Rothamsted Statistics Department (1973) Genstat Reference Manual. Scientific and Social Sciences Program Library, UK.

11. Applegarth, D. A. \& Ross, P. M. (1975) Clin. Chim. Acta 64, 83-85.

12. Clark, L. C., Thompson, H. L., Berk, E. I. \& Jacobson, W. (1951) Am. J. Dis. Child. 81, 794-783.

13. Calles-Escadon, J., Cunningham, J. J., Snyder, P., Jacob, R., Huszar, G., Loke, J. \& Felig, P. (1984) Am. J. Physiol. 246, E334-E338.

\section{A. J. Speek}

TNO-CIVO Toxicology and Nutrition Institute Department of Clinical Biochemistry P. O. Box 360

NL-3700 AJ Zeist 